\title{
ANALISIS FUNGSI KAWASAN BUDIDAYA DI KABUPATEN BONDOWOSO
}

\author{
Nevy Farista Aristin ${ }^{1}$
}

\author{
E-mail: nepharistin@gmail.com
}

\begin{abstract}
Abstrak: Pertumbuhan wilayah suatu wilayah sangat bergantung pada sektor internal dan ekstrenal. Kebijakan struktur ruang dalam RTRW yang selama ini diterapkan di Kabupaten Bondowoso masih belum mampu untuk mengatasi disparitas wilayah yang terjadi. Atas dasar itu maka perlu adanya analisis fungsi kawasan budidaya di Kabupaten Bondowoso guna mencari keunggulan dari masing-masing wilayah yang ada. Metode yang digunakan adalah survey institusional. Teknik yang digunakan dalam pemilihan lokasi penelitian ini adalah purposive yaitu metode pemilihan lokasi berdasarkan pada tujuan penelitian. Penelitian ini dilakukan di Kabupaten Bondowoso dengan unit analisis berdasarkan unit populasi, yaitu seluruh kecamatan yang didominasi oleh kawasan budidaya di Kabupaten Bondowoso. Fungsi kawasan di Kabupaten Bondowoso didominasi dengan kawasan budidaya yang terdiri dari 17 kecamatan dari 23 kecamatan. Kawasan-kawasan tersebut memiliki fungsi yang didominasi oleh lahan sawah dan ladang. Pengelolaan kawasan budidaya yang ada di 17 Kecamatan di Kabupaten Bondowoso tersebut ditujukan dengan mendorong segala kegiatan perekonomian yang dapat meningkatkan pendapatan masyarakat dan memperkuat perekonomian daerah berdasarkan potensi yang ada. Ini nantinya dalam kawasan budidaya tiap kecamatan didasarkan pada potensi wilayah yang ada tanpa mengurangi ataupun merusak kawasan lindung yang ada di Kabupaten Bondowoso.
\end{abstract}

Kata kunci: Kawasan budidaya dan keunggulan wilayah

\section{PENDAHULUAN}

Kabupaten Bondowoso sebagai salah satu kabupaten di Propinsi Jawa Timur yang memerlukan suatu kebijakan pengaturan ruang sebagai pengarah perkembangan wilayah di masa yang akan datang. Hal tersebut didasarkan pada visi pembangunan jangka menengah daerah Kabupaten Bondowoso sebagaimana yang dirumuskan dalam kebijakan pembangunan daerah adalah "Terwujudnya Masyarakat Kabupaten Bondowoso yang Religius, Berkualitas, Berdaya Saing, Aman, Tertib, dan Sejahtera".

Dalam pelaksanaan visi tersebut maka akan dijabarkan dalam misi pembangunan Kabupaten Bondowoso, yaitu meningkatkan kualitas pendidikan, kesehatan dan sosial dasar lainnya, meningkatkan pengelolaan potensi ekonomi rakyat dan pengelolaan sumber daya alam secara optimal, dan mewujudkan pemerintahan yang bersih, adil, demokratis dan akuntabel serta situasi yang kondusif.

Pengaturan struktur ruang wilayah Kabupaten Bondowoso sangat diperlukan untuk menata pemanfaatan tata ruang kota itu sendiri. Dalam hal ini struktur ruang wilayah Kabupaten Bondowoso meliputi fungsi kawasan, hirarki wilayah dan interaksi wilayah. Pengaturan struktur ruang wilayah Kabupaten Bondowoso ini 
Nevy Farista Aristin. Analisis Fungsi Kawasan Budidaya

Di Kabupaten Bondowoso

diatur bagian dari Rencana Tata Ruang Wilayah (RTRW) Kabupaten Bondowoso.

Pemanfaatan fungsi kawasan untuk perencanaan struktur ruang wilayah Kabupaten Bondowoso ini dapat dilihat dari penggunaan lahan yang ada. Dalam hal ini penggunaan lahan sangatlah penting dalam menentukan fungsi kawasan yang ada. Untuk itulah, fungsi kawasan ini nantinya akan dibagi menjadi kawasan lindung dan kawasan budidaya. Dengan adanya penentuan fungsi kawasan yang ada di tiap kecamatan di Kabupaten Bondowoso tersebut nantinya akan diketahui pengembangan fungsi kawasan tersebut untuk arahan kebijakan pembangunan Kabupaten Bondowoso yang seimbang dengan nilai ekologis atau lingkungan yang ada.

Penggunaan lahan di Kabupaten Bondowoso tahun 2007 sebagian besar didominasi dengan pertanian lahan kering, hutan lindung, dan pertanian lahan basah (sawah). Penggunaan lahan tersebut dapat disimpulkan bahwa fungsi kawasan Kabupaten Bondowoso didominasi oleh kawasan budidaya seluas $1216,93 \mathrm{~km}^{2}$ atau sebesar $78 \%$ dari luas keseluruhan kawasan yang ada di Kabupaten Bondowoso.

Dengan adanya perbedaan fungsi kawasan dan atau hirarki wilayah yang ada di Kabupaten Bondowoso maka terjadilah interaksi antar wilayah. Interaksi antar wilayah ini dapat dilihat dari pendistribusian barang antar wilayah untuk memenuhi kebutuhan wilayahnya. Interaksi antar wilayah di Kabupaten Bondowoso sangatlah berperan penting dalam perkembangan setiap kecamatan yang ada sehingga nantinya dapat memperkecil ketimpangan antar wilayah yang ada.

\section{RUMUSAN MASALAH}

Dari uraian di atas, maka permasalahan pada penelitian ini adalah adanya dinamika wilayah dengan bertambahnya jumlah penduduk dengan luas lahannya yang tetap dan mendorong terjadi penyimpangan penggunaan lahan eksisting (perubahan pemanfaatan ruang). Penyimpangan tersebut telah tidak sesuai dengan perencanaan penataan struktur ruang wilayah dalam RT RW Kabupaten Bondowoso 2007-2026 sehingga perlu mengarahkan pemanfaatan fungsi kawasan yang ada di Kabupaten Bondowoso. Atas dasar tersebut maka fokus dalam penelitian ini adalah menganalisis fungsi kawasan budidaya tiap wilayah.

\section{METODE PENELITIAN}

Metode penelitian yang digunakan dalam penelitian ini adalah metode survey institusional. Teknik yang digunakan dalam pemilihan lokasi penelitian ini adalah purposive yaitu metode pemilihan lokasi berdasarkan pada tujuan penelitian. Penelitian ini dilakukan di Kabupaten Bondowoso dengan unit analisis berdasarkan unit populasi, yaitu seluruh kecamatan yang didominasi oleh kawasan budidaya di Kabupaten Bondowoso.

Data yang diperlukan adalah data sekunder yang didapatkan dari instansi yang terkait. Pengolahan data yang digunakan dalam penelitian ini adalah pengolahan statistik dengan menggunakan Microsoft excel dan pengolahan spasial dengan program arcview. 




\section{Gambar 1. Lokasi Penelitian}

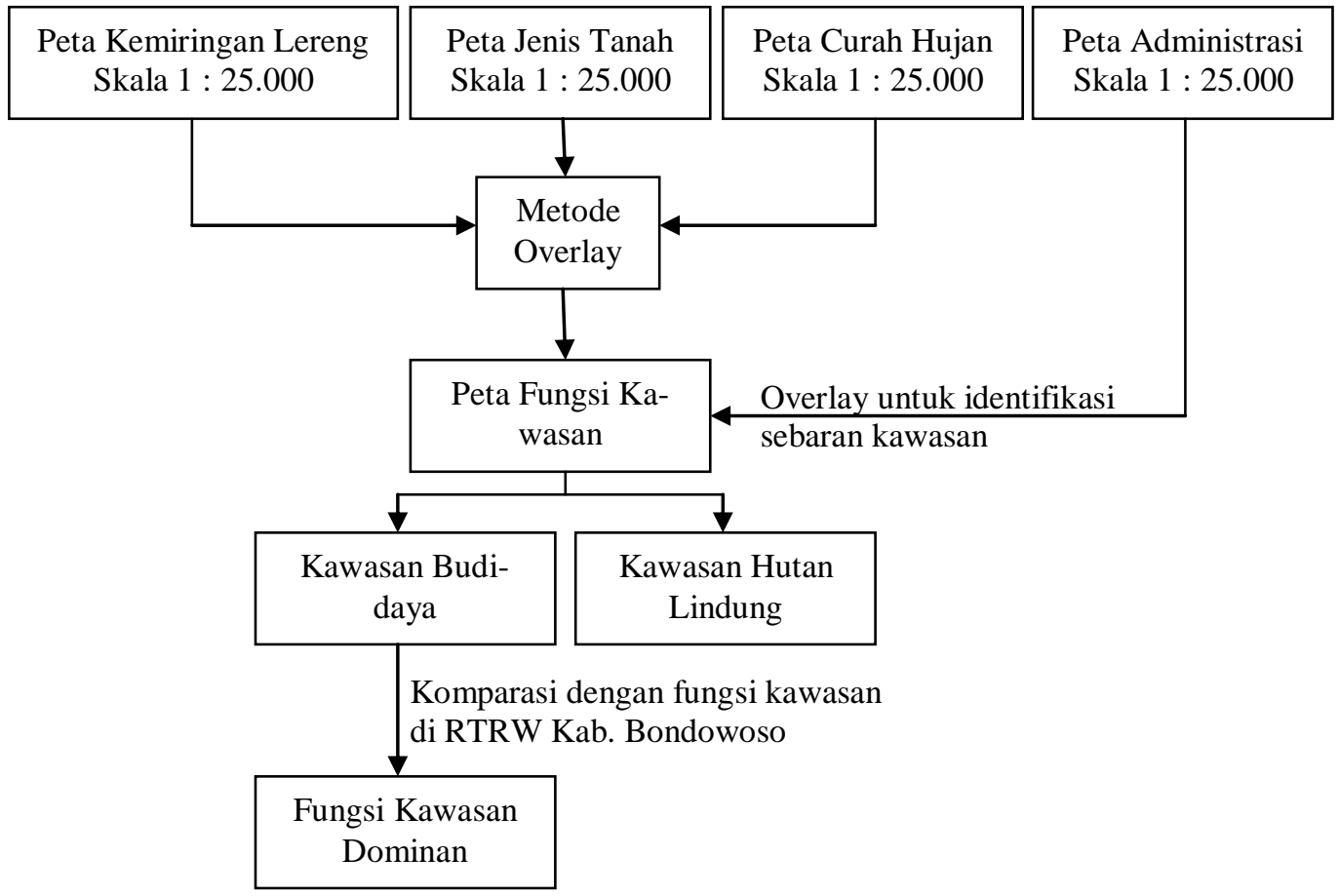

Gambar 2. Diagram Alir Penelitian 
Nevy Farista Aristin. Analisis Fungsi Kawasan Budidaya

Di Kabupaten Bondowoso

\section{HASIL DAN PEMBAHASAN}

Luas wilayah keseluruhan Kabupaten Bondowoso adalah 1560,10 $\mathrm{Km}^{2}$. Dalam hal ini, penggunaan lahan yang digunakan pada daerah ini adalah hutan lindung, suaka alam, hutan produksi dan hutan rakyat, perkebunan, pertanian lahan kering, pertanian lahan basah (sawah), permukiman, industri, dan perdagangan dan jasa. Dari penggunaan lahan tersebut maka fungsi kawasan yang ada di Kabupaten Bondowoso adalah kawasan lindung dan kawasan budidaya.

Dari hasil overlay antara peta kemiringan lereng, jenis tanah dan curah hujan menghasilkan peta arahan fungsi kawasan dan dihasilkan kecamatankecamatan yang didasarkan pada fungsi kawasan lindung dan kawasan budidaya. Berdasarkan hasil pengolahan data, dengan analisis spasial didapatkan bahwa Kabupaten Bondowoso didominasi dengan kawasan budidaya yang tersebar di 17 kecamatan yang ada dan 6 kecamatan lainnya masih berupa kawasan lindung yang masih dijaga fungsinya (perhatikan gambar 3). Kecamatan yang didominasi kawasan budidaya tersebut nantinya akan diarahkan untuk menjadi kawasan strategis ekonomi yang dikembangkan sesuai dengan potensi unggulan daerah masing-masing.

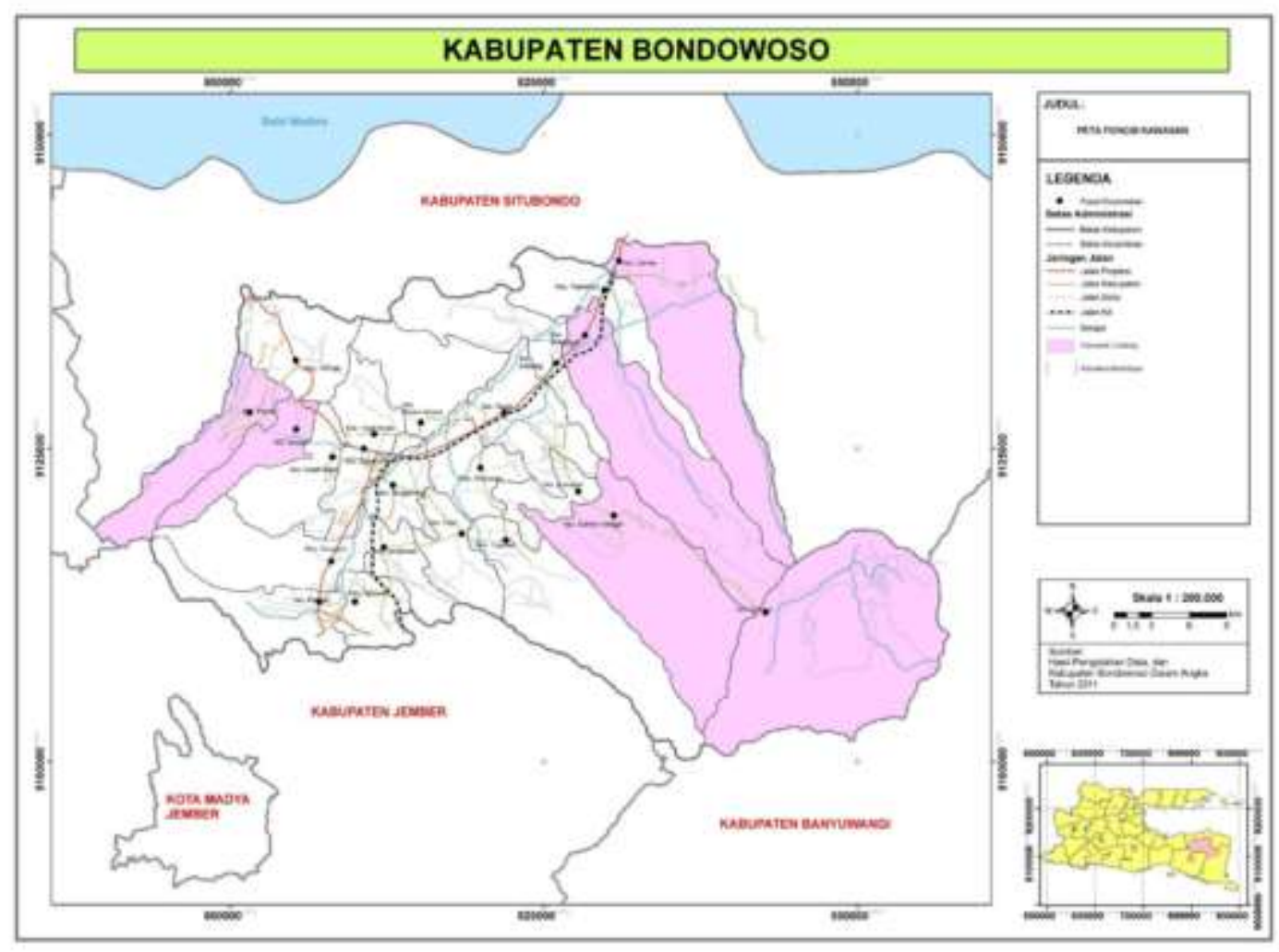

Gambar 3. Sebaran Kawasan Budidaya dan Hutan Lingdung di Kabupaten Bondowoso

Kecamatan-kecamatan yang mempunyai fungsi budidaya tersebut memiliki orientasi ekonomi dengan adanya potensi sektor unggulan dalam perekonomian 
wilayah Kabupaten Bondowoso. Dari komparasi dengan data fungsi kawasan dalam RTRW Kabupaten Bondowoso tahun 2007-2026 didapatkan hasil sebagai berikut.

\section{Tabel 1. Komparasi Hasil Analisis Overlay dengan Fungsi Kawasan Dominan}

\begin{tabular}{llll}
\hline No & Kecamatan & Fungsi Kawasan & Fungsi Kawasan Dominan (Sumber RTRW) \\
\hline 1 & Wringin & Kawasan Budidaya & Sawah \\
2 & Taman Krocok & Kawasan Budidaya & Sawah \\
3 & Tegal Ampel & Kawasan Budidaya & Sawah \\
4 & Bondowoso & Kawasan Budidaya & Permukiman perkotaan \\
5 & Curahdami & Kawasan Budidaya & Ladang \\
6 & Grujugan & Kawasan Budddaya & Ladang \\
7 & Maesan & Kawasan Budidaya & Hutan darat \\
8 & Tamanan & Kawasan Budddaya & Sawah \\
9 & Jambesari & Kawasan Budidaya & Ladang \\
10 & Pujer & Kawasan Budddaya & Ladang \\
11 & Tlogosarri & Kawasan Budidaya & Hutan darat \\
12 & Tenggarang & Kawasan Budidaya & Sawah \\
13 & Wonosari & Kawasan Budidaya & Sawah \\
14 & Tapen & Kawasan Budidaya & Sawah \\
15 & Klabang & Kawasan Budidaya & Sawah \\
16 & Prajekan & Kawasan Budidaya & Semak \\
17 & Sukosari & Kawasan Budidaya & Sawah \\
\hline
\end{tabular}

Sumber: Hasil Analisis dan Data Sekunder RTRW Kabupaten Bondowoso 2007-2026

Secara fungsional, kawasan budidaya ini merupakan kawasan yang memiliki beberapa jenis pemanfaatan, antara lain untuk kawasan pertanian, perkebunan, permukiman, perdagangan dan jasa, industri yang nantinya akan mempengaruhi perkembangan suatu wilayah yaitu Kabupaten Bondowoso.

Dalam pengelolaan kawasan budidaya ini Pemerintah Kabupaten Bondowoso dapat meningkatkan kegiatan pembangunan di segala bidang dan perekonomian daerah tanpa mengesampingkan aspek lingkungan hidup, sebagaimana paradaigma universal yang berkembang yaitu pembangunan berkelanjutan (suistanable development). Seperti pada ada di RTRW Kabupaten Bondowoso, pengembangan kawasan budidaya ini merupakan segala upaya untuk peningkatan pendayagunaan lahan yang berada di luar kawasan lindung, untuk dimanfaatkan tanpa mengganggu keseimbangan dan kelestarian lingkungan hidup yang ada di sekitarnya. Pengelolaan kawasan budidaya yang ada di 17 Kecamatan di Kabupaten Bondowoso tersebut ditujukan dengan mendorong segala kegiatan perekonomian yang dapat meningkatkan pendapatan masyarakat dan memperkuat perekonomian daerah berdasarkan potensi yang ada. Ini nantinya dalam kawasan budidaya tiap kecamatan didasarkan pada potensi wilayah yang ada tanpa mengurangi atau merusak kawasan lindung yang ada di Kabupaten Bondowoso. Untuk mengetahui potensi wilayah yang ada nantinya akan didasarkan pada karakteristik wilayah tersebut sehingga nantinya dapat dikembangkan secara optimal untuk 
Nevy Farista Aristin. Analisis Fungsi Kawasan Budidaya

Di Kabupaten Bondowoso

meningkatkan perekonomian wilayah yang ada di Kabupaten Bondowoso.

\section{KESIMPULAN DAN SARAN}

Fungsi kawasan di Kabupaten Bondowoso didominasi dengan kawasan budidaya yang terdiri dari 17 kecamatan dari 23 kecamatan. Kawasan budidaya yang ada di dominasi oleh sawah pada 9 kecamatan yaitu Kecamatan Wringin, Taman Krocok, Tegal Ampel, Tamanan, Tenggarang, Wonosari, Tapen, Klabang, dan Sukosari. 4 kecamatan dengan kawasan budidaya yang didominasi oleh ladang, yaitu, Curahdami, Grujugan, Jambesari, dan Pujer. Kecamatan Maesan dan Tlogosari memiliki fungsi kawasan budidaya hutan darat. Dan Kecamatan Bondowoso memiliki fungsi kawasan yang dominan untuk permukiman.

\section{DAFTAR PUSTAKA}

Adams,N., Alden,J.,and Harris,N. 2006. Regional Development and Spatial Planning in an Enlarged European Union. Urban and regional Planning and Development Series, pp.1-14.

Albrechts,L. 2004. Strategic (Spatial) Planning Reeaxamined. Environment and Planning B: Planning and Design, 31,pp.743-758.

Algifari, Drs.,M.Si. 2003. Statistika Induktif Untuk Ekonomi dan Bisnis. Yogyakarta: Unit Penerbit dan Percetakan Akadaemi Manajemen Persahaan YKPN.

BAPPEDA Kabupaten Bondowoso. 2007. Rencana Tata Ruang Wilayah Kabupaten Bondowoso Tahun 2007-2026. Bondowoso: BAPPEDA Kab. Bondowoso.
BPS. 2011. Bondowoso Dalam Angka 2010. Bondowoso: BPS Kabupaten Bondowoso.

Darwanto, H. 2000. Sterategi Kebijakan Propenas Bidang Penataan Ruang Makalah Di Sajikan Dalam Pelatihan Penataan Ruang Provinsi di Jakarta. Jakarta: Direktorat Penataan Ruang 85 Daerah, Departemen Pemukiman dan Pengembangan Wilayah.

Catanese,Anthony J dan Snyder,James C. 1996. Urban Planning Second Edition. Jakarta : Erlangga.

Cheema, G. Shabbir (ed.), 1993. Urban Mangement and Innovation in Developing Countries. London: Preager Publishers.

Christaller, W. (1966 (1933)). Central Places in Southern Germany. Translated by C.W. Baskin. Englewood Cliffs: Prentice-Hall.

Manta, Kalla. 2006. Fungsi dan Hirarki Kota. Perencanaan dan Pengembangan Wilayah Universitas Hasanuddin, Makassar.

Muryono. 2008. Arahan Fungsi Pemanfaatan Lahan Daerah Aliran Sungai Samin Kabupaten Karanganyar dan Kabupaten Sukoharjo Tahun 2007. Skripsi. Surakarta: Universitas Sebelas Maret.

Peraturan Menteri Dalam Negeri No.1 Tahun 2008 Tentang Pedoman Perencanaan Kawasan Perkotaan.

Peraturan Menteri Pekerjaan Umum No.41/PRT/M/2007 Tentang Pedoman Kriteria Teknis Kawasan Budidaya.

Polat, Erkan. 2009. A 'New And Soft' Urban Planning Paradaigm:The Strategic Spatial Planning. Debreceni Muszaki Kozlemenyek. Turkey: Department ofCity and Regional Planning. 
Rondinellis, Dennis A. 1985. Applied Methods of Regional Analysis The Spatial Dimension of Development Policy. London : West View Press.

Rondinellis, Dennis A. 1995. Applied Method of Regional Analysis. USA:Westview Press.

Suryono, Bambang. 2007. Hubungan Tipe Wilayah Pertanian Dengan Tingkat Perkembangan Wilayah Kabupaten Sleman. Skripsi S1. Yogyakarta: Fakultas Geografi UGM.
Tarigan, Robinson. 2008. Perencanaan Pembangunan Wilayah. Jakarta: Bumi Aksara.

Tewdwr-Jones,M. (2004). Spatial Planning: Principles, Practices and Cultures. Journal of Planning and Environment Law, May, pp. 560569.

Tika, Moh.Pabundu. 2005. Metode Penelitian Geografi. Jakarta: Bumi Aksara.

Yunus, Hadai Sabari. 2009. Klasifikasi Kota. Yogyakarta: Pustaka Pelajar. 